\title{
Strategies of Integrating Public Participation in Governance for Sustainable Development in Kenya
}

\author{
Maurice Simiyu Nyaranga ${ }^{1^{*}}$ Prof Chen Hao ${ }^{1}$ Duncan Omenda Hongo ${ }^{2}$ \\ 1. School of Management, Jiangsu University P.O Box 301 Xuefu Road, Zhenjiang, Jiangsu Province, China \\ 2. School of Finance and Economics, Jiangsu University P.O Box 301 Xuefu Road, Zhenjiang, Jiangsu Province, \\ China
}

\begin{abstract}
Public participation is currently the famous tool of promoting transparency, accountability and effectiveness of any modern government. Kenya adopted this system of engaging citizens in governance when the new constitution was promulgated in 2010 that ushered in a decentralized system of government. This process has however been faced with challenges. Instead of reducing conflicts between government and the public, it has heightened witnessing so many petitions of government missing on priorities in terms of development and government policies. Using analytical survey approach, this study looks into what is happening in the day-to-day running of the devolved units of government and what can be done to avert the worsening ties between government and the public. Questionnaires were used to collect primary data which was subjected to descriptive statistics. On the findings, it emerged that the government is the main problem to promoting Public participation as regimes focus more on what they talked to people during campaigns and not what people need. There is great political interference ranging from ferrying a section of people, paying and coaching them to support unpopular government program. The findings also shows that the government tries to lock out citizens during participation process by giving a short notice and not designating venues for public participation events. The study concludes with strategies of enhancing public participation and reduce negative political influence by establishing an independent commission/institution or agency that will be incharge of public participation and coordination development programs.
\end{abstract}

Keywords: Public Participation, challenges of Public Participation, Strategies of enhancing public participation, sustainable Development

Compliance with Ethical standards: We complied with the ethical standards of the journal.

Conflict of Interest: The authors declare to have no conflict of interest.

Author's consent: The aforementioned authors had a unanimous consensus to all processes undertaken towards the paper.

Research Funded by: Prof Chen Hao; School of Management, Jiangsu University; 212013

DOI: 10.7176/PPAR/9-7-06

Publication date:July $31^{\text {st }} 2019$

\section{Introduction}

Public Participation is the process through which the government engages citizens in decision-making and implementation of government programs. The public may consist various stakeholders- individuals, interest groups and communities who have a stake in the issue in contention. It is actually giving the opportunity to this group to state what they wish to happen. These stakeholders may hold an array of views/ideas/concerns, hence, providing a fair treatment regardless of their socio-economic and political orientation, with respect to the development, implementation and decisions made. Through Public participation of the civil society in decisionmaking, agreement is reached on the most important challenges that local communities face. This would have an impact on the quality and effectiveness of a policy, program or plan of the government is offering solutions to this challenge. Public Participation process provides the government a wide spectrum of ideas upon which decisions can be drawn from to meet the pertinent issues facing the stakeholders involved (USEPA, 2017).

Cogan and Sharpe (1986) identifies the benefits of public participation to the planning process: Public Participation provides Information and ideas on public issues, it also provides Public support for planning decisions, facilitates avoidance of protracted conflicts and costly delays and provides spirit cooperation and trust between the agency and Public. A well-planned public participation therefore relates the expectations of the citizens and the Government hence reducing the disparities. The idea of institutionalization of Public participation was initiated in mid 1960 s by the $36^{\text {th }}$ president of United States, President Lyndon B. Johnson (Cogan \& Sharpe 1986). In modern society, laws envisaged in the constitution regulate direct engagement of citizens.

Currently, Public participation is the focus by the European democracies. It is interesting to note that public participation is also gaining roots in Asia with China on the frontline (Ling Li et al 2018). Elections in these countries are one of the platform provided for the public to influence their government. In Cyprus national policy for instance, public participation is denoted in the European Union Treaty and National level through 
Town and Country Law (1990 - 2013). In United Kingdom, they have devolved responsibilities to assemblies of Scotland, Wales and Northern Ireland. Among these is the power to determine ways of making decisions. In England, though not devolved, the government policy is to give citizens a much stronger voice in policymaking and where necessary transfer control of government assets to citizen groups. Germany also identifies high level of civic participation. Over three decades, the country has integrated participatory structures in urban planning. Finally, in United States, the power to plan is divided among cities, counties, school and special districts, regional; authorities and state governments. Decisions emerge after bargaining and compromise between them. These units enjoy autonomy to allow innovation and creative problem solving. Hence, Participation in US is deep (EUKN, 2013; Fagence, 1973).

African countries have also metamorphosed with elections, multi-party civil and human rights taking center stage paving way for citizen to participation of citizens in political and public discourse and allowing people to have a say in decision-making process. Most of the African Government, currently affords protection of human rights and fundamental freedom. They promote rule of law, which implies that all people and institutions are subject to and accountable to the law (Rossouw, M., 2019).

Kenya, like many other countries in Africa countries has made historic transitions. The most recent one is the promulgation of the new constitution in 2010, that ushered in decentralization of powers of governance and other policy development roles to local/sub national governments called counties.

The Constitution provides for participation of citizens in exercise of powers of the state and in making decisions through indirect and direct involvement of the people in the process of policymaking. This would enhance responsible governance and accountability to the people as well as community-based monitoring and advocacy for transparency and accountability.

Good governance means legitimate, consensual, transparent, efficient, effective and fair. Most important, it takes place through participation of people, who set goals and priorities and participate in their implementation. This makes public participation a prerequisite to achieving good governance (NHDR, 2001). Good governance therefore having conditions and mechanisms that would ensure constant and continuous efficient interaction among the citizens and the government officials mandated to for decision making at different levels and in all aspects of governance.

Public Participation in governance would deal with array issues of that would make governing difficult. Due to structural adjustment and growth exhibited in the world, social needs have become complex. Issues such as social exclusions, inequalities in health, education, and other services from the government, community regeneration elude traditional hierarchical instruments of governance. In such societies, it is practically hard for the government to determine social development (Kooiman 1999, 2000). The role of state changes from governing to governance.

Interactive planning in governance promotes information, feedback consultation and negotiation. This open planning leads to better decisions that would be accepted by different stakeholders. The focus would be on what was agreed upon. The government would focus more on implementing the outcomes of citizen engagement. Success of these governments depends the achievement of the agreed action plan (Lang 1986). Furthermore, Lang argues that much of planning practices dominated by a perspective of technical rationality. However, other perspectives such as organizational, political and personal influence resource planning.

Bang (2002) argues that states lack governance capacities simply because they are inclined more to coping with abstract problems and interest conflicts than dealing with concrete policy and identify problems.

Public participation process provides a platform for development of more creative and innovative solutions in a variety of perspectives to environmental problems Brody, 2003; Coenen, 2008; Fritsch and Newig, 2012; Layzer, 2008) It helps in integration of different types of knowledge in decision or policymaking process (Fung, 2006).

For a policy, program, project or plan to be sustainable, it must put into consideration three dimensions: Economic growth, social equity and ecological integrity. Rarely do these dimensions balance among themselves. They are depending on the local needs and circumstances. Hence, the concept of sustainability varies from one project to another. Public participation informs decision makers on critical knowledge and wisdom to planning and designing the project and clarifying the degree which stakeholders are willing to accept or live with the trade-offs. This enables the government to make better informed and integrated decisions about sustainability of any project, program or policy that the government wishes to venture in participation would also reduce the government citizen conflicts that would emanate over lack of consultations that results into imposed government policies that attract resistance on account of citizen opinions being ignored. The essence of public participation is to begin a participatory process before crisis erupts. The government would be proactive in mitigating the threats of failure of their programs. It creates trust and public ownership of government initiatives leading to a collaborative process of implementing government projects or policies. Otherwise, if ignored, citizens may be number one enemies of such government initiative hence; they may suffer sabotage (Hardy, M. 2015).

After the promulgation of the new Constitution in 2010, power and functional units were transferred to 
county governments. Besides voting, citizens could be involved in development programs right from conception to the entire process of implementation. Public Participation meant to provide a great platform for the citizen to deliberate on government issues. As Fung (2015) argues, there was a weakened bond between government and citizens. The innovation of citizen participation is a mechanism to strengthen this bond.

However, six years of devolution and it seems these ambitions were only on paper. With all indications showing a demanding citizen for their rights and adherence to the constitution, courts have witnessed a series of petitions against both national and county governments for failing to follow the due process as required by the law. S.S.A. Aly \& M. S. E. Amer (2011) elucidates that public stakeholders have the ability to influence decisions and therefore the Egyptian government should have the ability manage conflicts, deal with public anger and aggressive behaviour and gain public trust. This shows indeed, that there is a widening gap and a growing mistrust between government and the public, which would derail development. As Beresford argues on the contradictions in public participation, leaders have prioritized political interests, public dissatisfaction, official priority with limited achievements and resourcing. (Beresford, 2002).

Despite the legal provisions for a participatory government, there is little to about. The new constitution is being viewed as an enemy especially when the government has failed to follow such provisions to the latter. The previous literatures in this subject have delved in identifying the challenges facing implementation of public participation as well as encouraging various stakeholders to embrace it. Bang (2002) called for project politics and politics of presence. He underscored on how to engage citizens in helping solving policy problems and enable citizens' voice their interest, experiences and identities in deliberative process. This study seeks mechanisms to bridging this gap.

\subsection{Literature Review}

Public participation has attracted a host of scholars. Abelson, J. et al (2003) in the review of literature, explore the recent fascination with deliberative methods for public involvement. First, they examine their origins within democratic theory, and second they focus on the experiences with deliberative methods within the health sector. They conclude that for citizens to effective and pivotal in the process of decision-making, there is need to be well informed about the subject of deliberation. Devas, N. \& Grant, U. (2003) echoed these sentiments, however, they interject that all these does not guarantee that decentralised decision-making will be inclusive of the poor.

Chris Aulich (2009) in his article from Citizen Participation to Participatory Governance in Australian Local Government; identifies types of citizen participation in local government in Australia. The article focuses on the reforms that have been integrated in government system in the more than two decades and how participatory governance has taken roots in both national and sub national governments. He concludes that despite these reforms with an intend of engaging citizens in government activities, citizen participation is yet to develop significantly to reach the arrangement level of a participatory governance.

Okello, N. et al (2014) in the article; "The doing and un-doing of public participation during environmental impact assessments in Kenya" notes that restrict on participation during environmental decision-making in Kenya still exists. They identify barriers to public participation as follows; inadequate enforcement of the regulations that promulgate public participation, information inaccessibility, inadequate awareness on their roles, incomprehensive language and incomplete regulation. On the same thread; Ling Li et al (2018) their article "Public participation in achieving sustainable development goals in China: Evidence from the practice of air pollution control" they argue that though public participation is in infancy in china and hence it is facing many challenges. Using the difference in difference approach, the research uses the newly released map, a product of public participation as a tool in assessing its impact in protecting environmental pollution. They find that release of the map reduced industries pollution intensity and marginal effect increases with time passing by, yet with a certain degree of fluctuation. This shows that the participation of multiple parties in environmental protection will reduce pollution. They conclude that government should provide good atmosphere by virtue of being the driver of the whole process. They propose amendment of the law to accommodate public participation on better grounds, sharing data with citizens, making use of media to inform the public among other measures to enhance participation

Archong Fung (2015) in his article of Public administration review takes stock of claims about the potential of citizen participation to advance three values of democratic governance: effectiveness, legitimacy, and social justice. He alludes that due to constraints and increased demands for individual engagement and technological advancements has paved way for a participatory innovation in quest for an effective On the other hand, government citizen relationship has weakened with time. The governments are in constantly seeking legitimacy from the citizens. This has necessitated the government to create citizen participation a way of enhancing legitimacy. However, the impact of these efforts are yet to be realized. The quest for promoting social justice through public participation has equally faced challenges.

Ronoh, et al. (2018) agrees with Archong as he discusses further the challenges facing public participation in Kenya. Using primary data from three of the forty-seven sub-national governments in the country, he notes 
that negative attitude towards public participation, lack of willingness of the public to participate, lack of political goodwill, lack of capacity to participate, political interference, demand for incentives and lack of time by the citizens are some of the challenges public participation faces.

The above literatures are more inclined to exploring the challenges facing the implementation of a participatory governance. Drazkiewicz, A., Challies, E., \& Newig, J. (2015) in their article "Public Participation and local environmental planning" explain the importance to participation in improving the quality of decision making in solving environmental problems. They however, suggest a further research on which factors lead to success of decision making in different settings. This study is inclined to such suggestions to add new literature on how to mitigate these challenges for full transition from a hierarchical government to a more collaborative governance that would have an impact on decision and policymaking hence a great impact on development.

\subsection{Empirical Methodology and Research Data}

This study was conducted through the analytical survey approach (theory testing) where authors used available information and primary in analysis and critical evaluation. This paper examines the association between variables: Public Participation, Governance and Sustainable Development.

Online method of data collection used because it is affordable in allowance to reach audience within a short period of time, so it is cost effective especially for the researcher who is far from the location that data is supposed to be collected. It saves on travelling costs and reduces risks for the researcher. Yun \& Trumbo, 2000; Tuten, et al., 2000 backs this method as advantageous for speedy distribution and response cycle, environmentally friendly as there is no paper work and it is the best for addressing sensitive questions as the interviewer is not present. Okello, et al., (2012) successfully used online method of data collection in their article "The doing and un-doing of public participation during environmental impact assessments in Kenya". Data was analysed using SPSS software.

The target population for the study were adults from Bungoma County, who are above 18years as defined by Article 260 of the 2010 Kenya constitution and have internet access. The Kenya National Bureau of Statistics annual report (2016) projected 701,151 persons of eighteen years and above by the year 2018 in Bungoma County. The study will use proportionate stratified random for the public to respond the questionnaire. In determining the sample size, the study employs the formula suggested Fisher, et al (1983) in Mugenda \& Mugenda (2003) in estimation of sample sizes in social surveys as illustrated below

$$
\mathrm{n}=\frac{\mathrm{z}^{2} \mathrm{pq}}{\mathrm{e}^{2}}=\frac{(1.96)^{2} \times 0.5 \times 0.5}{(0.05)^{2}}=384 \text {; where } \mathrm{n} \text { is the sample size, } \mathrm{Z} \text { is the } 95 \% \text { confidence }
$$
which is 1.96 , e is the sampling error $5 \%, \mathrm{p}$ is the maximum variability of the population at $50 \%$ which is 0.5 and $\mathrm{q}=1-\mathrm{p}=0.5$. Population above 10,000 people the sample size is 384 (Fisher, et al 1983).

In that line, the questionnaire which was distributed online to respondents inquisitively demanded the respondents to fill in the requisitions basing on what extend they agreed with statements therein. They were to make their choices through ticking in the box spaces provided regarding; 1- Strongly Disagree, 2- Disagree, 3Neutral, 4- Agree and 5- Strongly Agree. The outcome of the process was then arranged and analysed then results presented in Table 1.

\subsection{Findings and Discussion Data Analysis}

The respondents were asked to what extend they agree with following statements. They were to make their choices through ticking in the boxes; 1- Strongly Disagree, 2- Disagree, 3- Neutral, 4- Agree and 5- Strongly Agree

Table 1. Descriptive Statistics

\begin{tabular}{lll}
\hline & Std. \\
& Mean & Deviation \\
\hline The government gives priority for citizen's opinions during Public Participation Process & 2.107 & 1.263 \\
There is Political interference/inclination with Public Participation & 3.706 & 1.194 \\
People are aware of the Public Participation as the provisions in the constitution & 4.190 & 0.918 \\
Respondent understand due public participation process & 3.906 & 1.020 \\
The government has created enabling environment for public participation & 2.779 & 1.253 \\
The government has Designated venues for public participation events & 3.073 & 1.198 \\
The citizens have time for public participation & 3.762 & 1.030 \\
The citizens understand the language and budgeting process & 3.273 & 1.276 \\
There is need for government to facilitate citizens in terms of transportation to venues & 3.508 & 1.348 \\
for participation & 2.480 & 1.382 \\
There is timely notice by the government for participation &
\end{tabular}

$\mathbf{N}$ is 384; Minimum 1.0 and Maximum 5.0 
The aim of this paper is to derive the strategies that could enhance integration of Public Participation in governance for sustainable development.

The aim of this paper is to derive the strategies that could enhance integration of Public Participation in governance for sustainable development.Therefore, regarding Table 1; the results show that the government does not consider what people say during public participation process as majority disagreed with the statement with a mean of 2.107 and a standard deviation of 1.263. This could be because, the government with the elected leaders, have their manifestos that they used in campaigns. They prioritize implementing their manifesto over meeting the real needs brought forward by the people. As Fung (2015) argues on putting participation in governance, that citizen participation has been rendered trivial. Hence, what people say or need is not a priority. Instead, leaders push for what they think favours them in implementation and not what people say.

Majority respondents think there is political interference and or inclinations during the process of Public Participation with a mean of 3.0706 and a standard deviation of 1.194 . This could be because, the organizers of the event are chosen by the County governor and therefore only those who agree with what he/she deems to be his objectives are picked to spearhead the program. The government do also sensitize people about the program; citizens could not have time to delve into details of the program. All they meet are crafted leading questions that only require a yes or no answer. Another reason could be the government ferry people who they have compromised to agree with what the government wants to do. They act as the cheering squad and sometimes would boo those who may not agree with the government intentions. In case the ferried people are not enough, people present are coerced and bribed with money to buy into the idea of the government. This doubles up with majority disagreeing that government has created an enabling environment for Public participation with a mean of 2.779 and a standard deviation of 1.253. In addition, some public participation events are organized secretly if the government is aware people may not agree with their program.

Majority respondents agree that there are no designated venues for public participation events with a mean of 3.073 and a standard deviation of 1.198. This could be because the government has failed to provide the venues in order to get people unprepared to access the venues for the program. Some of the events; venues are communicated on the eve of the material day. Hence, citizens who may not be nearby the venues are disadvantaged. On the same line, the notice for these events is not timely delivered to the public. Majority respondents disagree that there is timely notice delivery to the public for public participation with a mean of 2.480 and a standard deviation of 1.382 . This could be politically driven as the government wants to carry out the function as a formality and not procedurally to get the feedback from the public. Some of the government programs are very unpopular and people would not agree with them. To ensure that the program goes on as the government wishes as well as meeting the demands of the constitution, the government only does all manner of things to minimise citizen involvement. Those public participations become events to sanitize the programs but they are not genuine.

On the other hand, the public is very much aware of the public participation process as per the constitution with a mean of 4.190 and a standard deviation of 0.918 . This could be because of the current dispensation where accessibility to information is easier through different platforms ranging from social media, televisions, internet access, and print media like newspapers and journals. Although, the government has done little to create this awareness due to their political interests that wishes to keep public uninformed, on contrary, the citizens understand the provisions in the constitution. This doubles up with understanding the due process of public participation with a mean of 3.906 and a standard deviation of 1.020, understanding of the language and budgeting process. This evident in petitions between the citizens and government where the government is being accused of not following due process in the implementation of certain programs or adoption of any policy. Unlike Ronoh et al (2018), findings where citizens were not aware of the process, did not understand the language used and budgeting process; this is a different finding showing a more informed public. Scholars initially cited lack of capacity by citizens for government's resistance to participation by the poor, who generally are less or not educated, high level of illiteracy and hence their understanding of the policy making process is practically difficult (Anwar, 2007).

There is time by citizen to attend public participation events with majority agree with the statement that they have time for participation with a mean of 3.762 and a standard deviation. Although citizens might be busy as Ronoh et al (2018) with other day-to-day activities for a living, they have however indicated that given a notice on time with clear indication of the venue for the event, they are ready to attend as they cite good programs from the government would change the socioeconomic status. However, majority too agree that the government should facilitate them to attend the events with a mean of 3.508 and a standard deviation of 1.382 . This is because, some say, the government facilitates a section of the crowd that would rubber stamp their formed questions and agree with everything the government says, otherwise, it is their constitutional responsibility as well as right to participation and they feel it is not necessary but since the government has already started with just a selectively picked group of people, it should cut across. 


\section{CONCLUSION}

Concisely, poor governance poses the main challenges bedevilling integration of public participation in governance. Based on these findings, the study develops strategies that could be employed to enhance integration of public participation in governance;

Institutionalization of Public Participation process. Public participation has been handled casually just with a mere fact of being a legal provision. This has made the regimes to take charge instead of the government. Just like provision of other services by the government after one regime leaves office, so it should be for public participation. The government through legislation should establish an independent commission that would spearhead matters of public participation away from politicians who manipulate the process to suit their interests. In this case, the commission will convene forums for participation for citizens and leaders. Politicians who have their manifestos if elected, they will play a ceremonious oversight of government programs, their manifestos would be submitted to the independent commission for consideration by different stakeholders of the public on the feasibility and urgency. This will reduce the chaotic political environment within which sustainable development is supposed to be realized. Whereas we appreciate that development is political, politics has to be on the equilibrium with development, but in a situations where politics and pessimistic interests takes precedence over public need and sustainability, flaw results are inevitable. As He (2014) argues, institutionalized reforms of governance are persistent, procedural and substantive development.

Moreover, politicians fear being audited by anyone they do not "trust". Public Participation was to create transparency and accountability. Allowing political leaders and regimes to spearhead public participation process which means they have are to audit themselves. To what extend can this be achieved? In developing countries like Kenya where the economy is struggling to gain roots and corruption is rampant, it is difficult for the system to be transparent if leaders do not view public participation as a mechanism to put the government on check by the people. Institutionalization will therefore change public participation from a favour to a social political and economic right to engage the public in government programs.

Members of the Agency or commission for Public Participation should be employed by the Public Service Board as opposed to being a presidential or governor's appointment and vetted by the National assembly or county assembly. This will reduce the politics that may surround their activities. Appointment might mean serving interests of the authority that placed you in office and not the public. Commissioners are employed on a contract based with provisions of being recalled by the service board for incompetency. Recruitment will be on merit as opposed to political affiliations. This will bring on board technocrats and expertise ranging from economists, lawyers, governance specialists, Public Administrators and Political scientists that would spearhead a sustainable public participation process.

Constant communication between the government and the public. There is a great lack of communication especially from the government. The government can also exploit other avenues of communicating to citizens. Apart from mainstream media and website, use of social media can also be instrumental in providing people with information on government activities. As Papacharissi (2010) puts it, social media creates new sphere of participants. It collapses the boundaries between private and public space and individuals' engagements have significant impact on the public sphere. Social media therefore provides a new platform that if well handled; it is effective and open for the target public to opine within their vicinity. It is convenient because it does not involve citizens moving from one place to another and probably even those who are inconvenienced by their day-to-day activities would spare their time for the exercise online. Communication should not come as accidental to the public but with intentions of conveying information and enlightening the public on plans and programs of the government as well the role need to be played by the citizens. This can only be possible is the urgency mandated to spearhead participation process is effective. Through it, citizens will get all the communications about what the government intends to and where their input is required. For publications and other records, the citizens would visit the functional website to familiarize themselves with government programs.

Information for everyone and treating all citizens across the political divide equally and with same obligation to deliberate on matters of public interest. Capacity building on specified issues to deliberate. Citizens encounter information on the day of participation, when they have not familiarized themselves with the program. The devil is in the derails and people should be made to understand the details in any government program. The urgency for public participation would carry out activities of sensitizing the public on specific government programs. Organizing for public forums where deliberations on policies to be adopted for better governance. Carrying out civil education to further empower citizens on what is expected of them.

\section{References}

Abelson, J., Forest, P. G., Eyles, J., Smith, P., Martin, E., \& Gauvin, F. P. (2003). Deliberations about deliberative methods: issues in the design and evaluation of public participation processes. Social science \& medicine, 57(2), 239-251.

Anwar S. (2007) Participatory Budgeting. Washington, DC: The World Bank. 
Aly, S. S. A., \& Amer, M. S. E. (2011). Public involvement in sustainable development: A public participation process in the Sidi Gaber railway station development project, Alexandria, Egypt. WIT Transactions on Ecology and the Environment, 150, 537-552.

Archon Fung (2015). Putting the Public Back into Governance: The Challenges of Citizen Participation and Its Future. Harvard University.

Aulich, C. (2009). From citizen participation to participatory governance. Commonwealth Journal of Local Governance, (2), 44-60.

Bang, O., Krolikowski, W., Wyller, J., \& Rasmussen, J. J. (2002). Collapse arrest and soliton stabilization in nonlocal nonlinear media. Physical Review E, 66(4), 046619.

Beresford, P. (2002). User involvement in research and evaluation: liberation or regulation?. Social policy and society, $1(2), 95-105$.

Betts, S. C. (2005). Contingency Theory: Science or Technology. Journal of Business and Economic Research, Vol. 1, No. 8. Retrieved on 22.10 .14 from http//www.wpunj.edu/theory

Cogan, A., Sharpe, S., \& Hertzberg, J. (1986). Citizen participation. International City Managers Association/American Planning Association, Chicago, 283-305.

Devas, N., \& Grant, U. (2003). Local government decision-making-citizen participation and local accountability: some evidence from Kenya and Uganda. Public Administration and Development: The International Journal of Management Research and Practice, 23(4), 307-316.

Drazkiewicz, A., Challies, E., \& Newig, J. (2015). Public participation and local environmental planning: Testing factors influencing decision quality and implementation in four case studies from Germany. Land Use Policy, 46, 211-222.doi:10.1016/j.landusepol.2015.02.010

EUKN (European Urban Knowledge Network), 2013 Urban Shrinkage and the Need for Civic Engagement https://www.eukn.eu/fileadmin/Files/Publications/EUKN_Publication_Shrinking_Areas.pdf

Fagence M T, 1973, "Citizen Participation in the planning process (United States)" Journal of the Royal Town Planning Institute 59 188-191

Fung, A. (2015). Putting the public back into governance: The challenges of citizen participation and its future. Public Administration Review, 75(4), 513-522.

Fung, A., 2006. Varieties of participation in complex governance. Public Administration Review 66 (s1), 66-75.

Hardy, M. (2015). Reflections on the IAP2 Spectrum [Blog post]. Retrieved 13 February, 2017 from http://maxhardy.com.au/reflections-on-the-iap2-spectrum/

IAP2 (International Association for Public Participation), 2017. Advancing the practice of public participation. https://cdn.ymaws.com/www.iap2.org/resource/resmgr/pillars/2017_code_of_ethics-24x36_ia.pdf

Kenya, Ministry of Devolution and Planning (2016): County Public participation guidelines

Kooiman, J. (1999). Social-political governance: overview, reflections and design. Public Management an international journal of research and theory, 1(1), 67-92.

Kooiman, J., \& Van Vliet, M. (2000). Self-governance as a mode of societal governance. Public Management an International Journal of Research and Theory, 2(3), 359-378.

Lamidi, K. O. (2015). Theories of public administration: an anthology of essays. International Journal of Politics \& Good Governance, 6(6.3), 1-35.

Láng, I. (1986). Impact on policymaking: background to a government decision. In Modelling and Managing Shallow Lake Eutrophication (pp. 110-121). Springer, Berlin, Heidelberg.

Manithaneyam, S. (2003). Theory of Administration. Retrieved on 19/10/14 from jaywin.com/pubresearch/index/scf

Mugenda, O. M., \& Mugenda, A. G. (2003). Research methods. Quantitative and qualitative approaches, $46-$ 48.approaches.

Newig, J., 2012. More effective natural resource management through participatory governance? Taking stock of the conceptual and empirical literature - and moving forward. In: Hogl, K., Kvarda, E., Nordbeck, R., Pregernig, M. (Eds.), Environmental Governance: The Challenge of Legitimacy and Effectiveness. Edward Elgar, Cheltenham, pp. 46-68

Newig, J., Fritsch, O., 2009. Environmental governance: participatory, multi-level - and effective? Env. Pol. Gov. 19, 197-214.

NHDR (National Human Development Report), 2001. http://hdr.undp.org/en/content/human-developmentreport-2001

OECD (1995). Governance in Transition: Public Management Reforms in OECD Countries. Paris: OECD

Okello, N., Beevers, L., Douven, W., \& Leentvaar, J. (2009). The doing and un-doing of public participation during environmental impact assessments in Kenya. Impact Assessment and Project Appraisal, 27(3), 217226.

Papacharissi, Z. 2010. A private sphere: Democracy in a digital age. Cambridge: Polity Press.

Ronoh, G., Mulongo, S.L. \& Kurgat, A. (2018). Challenges of Integrating Public Participation in the Devolved 
system of Governance for Sustainable Development in Kenya. Moi University, Eldoret, Kenya

Rossouw, M. (2019). Public Participation: An Imperative for Governance and Human Rights - Lessons From South Africa. http://futureafricaforum.org/2019/03/04/public-participation-an-imperative-for-governanceand-human-rights-lessons-from-south-africa/

Taylor, C. (1985). Social Theory as Practice. In C. Taylor (Ed.), Philosophy and the Human Sciences: Philosophical papers 2 (pp. 91-115). Cambridge: Cambridge University Press

The Kenya National Bureau of Statistics annual (2016) https://www.knbs.or.ke/download/statistical-abstract2016/

UN World Public Sector Report (2008). People Matter Civic Engagement in Public Governance. United Nations New York, 2008

USEPA (United States Environmental Protection), (2017). Public Participation Guide: Workshops; https://www.epa.gov/international-cooperation/public-participation-guide-workshops

Wikipedia (2014). Retrieved on 23.10.14 from http//www.wikipedia.org/theories

\section{Authors Biography}

1. Maurice Simiyu Nyaranga is a master's degree student at Jiangsu University (School of Management) specializing in Public Policy and Administration

2. Prof Chen Hao is fully fledged Lecturer in School of Management at Jiangsu University. He doubles up as the supervisor to Maurice Simiyu Nyaranga

3. Duncan Omenda Hongo is a master's degree student in Jiangsu University, School of Finance and Economics 